\title{
THE INFLUENCE OF VEGETATION TO INDOOR ILLUMINANCE, AIR TEMPERATURE AND RELATIVE HUMIDITY IN DESIGN STUDIO (Case Study: Architecture Department, Petra Christian University, Surabaya)
}

\author{
Wanda K. Widigdo ${ }^{1}$, Samuel Hartono ${ }^{2}$, Luciana Kristanto ${ }^{3 *}$, Danny Santoso Mintorogo ${ }^{4}$ \\ ${ }_{1,2,3,4}$ Department of Architecture, Petra Christian University \\ Jalan Siwalankerto no. 121-131, Surabaya, Indonesia \\ *Corresponding Author; Email: lucky@ petra.ac.id
}

\begin{abstract}
This research aimed to find the influence of vegetation outside the window to indoor light and thermal in Design studio, Architecture department of Petra Christian University, Surabaya. The vegetation was Shibataea kumasasa, cultivated in planter boxes, 90-100 centimeter high. The data was collected from the West and North window, for condition with and without vegetation outside the window. The measurement was taken on March until May 2019, using Hobo U12-012 data logger for measuring air temperature $\left({ }^{\circ} \mathrm{C}\right)$, relative humidity (\%) and illuminance (lux). Beside those physical measurement, the perception of 89 students as building user was also taken. The measurement result from windows facing West and North with the vegetation, the lowest indoor air temperature was $27^{\circ} \mathrm{C}$ with an average relative humidity of $70 \%$. Meant it's at the upper edge of the comfort zoneof Bioclimatic Chart from Olgyay and Canada's National Occupational Health \& Safety Resource (CCOHS), so the indoor space was still uncomfortable and cooling was required to get into the comfort zone at warm humid climate. Result from lighting measurements obtained for west-oriented windows with vegetation outside the window, the highest illuminance was 350 lux at $02: 45 \mathrm{pm}$, as well as for windows facing North at $07.30 \mathrm{am}-04.45 \mathrm{pm}$ in range of 105 - 155 lux (highest). So, if there are vegetation outside windows, it will require electric lighting addition, because the illuminance are below the SNI 03-6197-2011which recommends 750 lux for design studio. Whilst the user respond from the questionnaire taken, stated that aesthetic vegetation was expected for natural element, blocked the penetration of solar radiation into indoor, and reduce glare to increase visual comfort without reducing luminous sufficiency for the visual activities in the design studio.
\end{abstract}

Keywords: Vegetation; temperature; light, indoor.

\section{INTRODUCTION}

Surabaya is in warm humid climate with hot outdoor air temperature and high humidity throughout the year. The rainy season occur on October until April, while dry season is in May until September. In October, the sun is passing right above Surabaya; in this month, according to Juanda climatic and meteorology station, the outdoor air temperature at noon is very hot around $22-34^{\circ} \mathrm{C}$, with $31-83 \%$ in relative humidity (Kelembaban, Tekanan udara dan Temperatur udara rata-rata per bulan, 2012-2014).

The climatic condition influence the indoor condition because the penetration of the sun radiation and daylight into the building through the windows and openings. Radiation which penetrated trough the windows, change into indoor heat and increase the indoor heat gain and also the indoor air temperature. The natural light could generate glare to building indoor. According to Szokolay, 27\% of sun radiation reach the surface of the earth or buildings as direct radiation, $23 \%$ as undirect radiation or diffuse, meanwhile $25 \%$ absorbed by the atmosfer, $20.5 \%$ reflected by the cloud and 5\% reflected by the ground surface (Szokolay, 1980).
Windows and openings should be designed to create indoor light and thermal comfort which required for indoor activity. In tropical region,it is difficult to reach indoor thermal comfort because the climate is generally above the comfort zone. To get the thermal and visual comfort, building design usually applied secondary skin, shading, etc. with various material and form. Facing the sustainable development issue with energy efficiency as priority, bring up an idea using vegetation to protect the disturbing sun radiation with excessive brightness which penetrated to indoor.

Vegetation has advantage for building planners and users for its natural and aesthetic properties, besides cheaper compared to other building materials; but its easiness to plant should be consideration. Therefore the local vegetation usually more suitable to be planted.Besides that,it has many positive values that humans need, for example: the leaves convert $\mathrm{CO} 2$ to $\mathrm{O} 2$; the green color of leaves that's very good for human eye health; it's ability to reflect the sun's radiation that hits it; and many more benefits.

The application of vegetation still raise question; because on one side it reduce sun radiation; but on the other, it can lower light and wind velocity that bring to 
higher humidity. Thus even reduce the energy for cooling, the energy for lighting and ventilation can be increase. Therefore the impact of vegetation outside the window to the temperature and light still need to be researched further. This research result will give benefit for architects in using vegetation effectively to protect certain window and opening from sun radiation, to optimize the energy use for lighting and room cooling.

\section{Tropical Climate, Thermal, Visual Comfort and Psychology of workspace}

The workspace in this study was a Design studio used by Architecture students with the main visual activity working on designing and drawing details. From the climatic data in 2012-2014, the air temperature average was $28^{\circ} \mathrm{C}$, and the relative humidity average was $75.7-79.1 \%$ (Kelembaban, Tekanan udara dan Temperatur udara rata-rata per bulan, 20122014). This climatic condition, are on the top edge of comfort zone in Bioclimatic chart (Olgyay, 1963), which the comfort zone criteria if the air temperature is in range $22-30^{\circ} \mathrm{C}$, with $18-78 \%$ relative humidity.

According to Canada's National Occupational Health \& Safety Resource (CCOHS) on Health and Safety Programs, 2019, comfort zone in tropical climate, the air temperature is in range $23-26^{\circ} \mathrm{C}$, with average relative humidity about $50 \%$, and air velocity $0,15 \mathrm{~m} / \mathrm{second}$.

Besides the thermal comfort for working in designing, also need a good illuminance of lighting to support visual activities.The visual activities in drawing are categorized as quite heavy with small details, it needs lighting illuminance 750 lux (SNI-036197-2011). Whereas the need for natural lighting, according to CIBSE, 1987 (Ibrahim \& Hayman, 2005) the recommended DF level is $5 \%$.

In the quality of space, said that in indoor environment, greenery plays an important role for the quality of space as well as for the user's psycological well-being, comfort and health. Most of the students in an University where the research conducted, believe that this kind of greenery project could improve the aesthetic value of the campus and the interaction with nature might affect the individual's psychology thinks to the stress reduction (Montacchini, Tedesco \& Rondinone, 2017).

\section{Vegetation review}

The use of vegetation in building design is increasing because of human awareness of the benefits of vegetation for human health. The benefits of vegetation for human health, among others, can be categorized in 4 main functions (Post graduate, 2012): Ecological function;A. reducing pollutants and producing oxygen. $\mathrm{B}$. Improving the quality of the local climate; which are:a) cooler temperatures, b) better air movement, and c) reduced dust.

Vegetation shade can also have the following effects: (a) the vagetation shadow effect can resist $70 \%$ of the sun's heat falling to the surface. (b) decrease the air temperature, it reduced from 5.5 to $1{ }^{\circ} \mathrm{C}$, when the average of air temperature is $32^{\circ} \mathrm{C}$, and it can go down from 2.5 to 5.5 ${ }^{\circ} \mathrm{C}$ when the average of air temperature is $21^{\circ} \mathrm{C}$. Vegetation has a cooling effect, until noon under the shade of vegetation will be $2.5^{\circ} \mathrm{C}$ cooler than outside the shade of vegetation. At night, the temperature is $1.3^{\circ} \mathrm{C}$ cooler than the surrounding environment.

C. Solar radiation control. The type of vegetation used will affect the degree of control the sunlight radiation, including: (a) green plants reduce up to $80 \%$ light penetration, (b) dense leafy vegetation can reduce light penetration between 51$54 \%$ and protect from direct sunlight along days, (c) shrubs and ground covers (reduce the temperature by radiation absorption and evaporation), and (d) on a hot day, grass can reduce 5.5 $7.8^{\circ} \mathrm{C}$ cooler than open ground.

Aesthetic and architectural functions benefits include: (a) affirmation of space, (b) giving atmosphere and character of the building, site and environment, (c) scale switching, (d) view controller, and (e) glare control

Economic function; help and increase economic activity, if it can be traded or used, such as vegetables or medicinal plants.

Social functions; especially for Green Open Space (RTH), because various green open spaces (RTH) can have historical value if preserved can increase tourism and economic potential.

Vegetation outside the window can be a green wall to shade the window. The main considerations for selecting shading the window with the aim of cooling, are cost versus effectiveness and shadowing time versus effectiveness (Robinette, 1983). The selection of vegetation as a shadowing tool, would be: economical, because it does not require "energy" and is easy to maintain; ecological, has minimal negative impact on ecosystems and aesthetically, adding aesthetic appearance to the building and in harmony with the environment (Szokolay, 1987). The vege- 
tation as controlling solar radiation can be through 4 ways (Robinette, 1983, ed.): absorption, especially the dark colored leaves (Miller, 1955); reflection, besides that the leaves absorb solar radiation (Geiger, 1957); radiation, in the form of long waves; and forward (transmission).

Vegetation used should be able to control the temperature of the outside air $\left({ }^{\circ} \mathrm{C}\right)$, indoor $(\%)$ relative humidity (RH) and the indoor light iluminanace (lux) of the studio, namely by reducing the penetration of radiation and sunlight into the indoor through window. So the vegetation needed, that can provide shading on the window. The vegetation that is capable of providing shadow can be planted in a planter box with a height of vegetation in accordance with the needs of the shadow or hung vegetation hanging over the window. This form of planting is called vertical greening.

The implementation of vertical greening facade on an office building clearly reduces the temperature and humidity of a building. His study has proved that vertical greening did effectively act as a passive approach towards sustainable building design in the urban area of tropical climate country. However, the grade of effctiveness depends on the type of greenwall design and the orientation of the facade toward the intense heat of the sun (Othman \& Sahidin, 2016).

Vertical Greenery System that consisted of Green Facade and Green Wall, could save energy in summer. This was achieved by reducing the external wall temperature (Coma J. et al., 2017).

Jaafar, Said, Reba, and Rasidi , 2013, compared climbing plants and modular system plant facades in reducing temperature of the building and cools the respective internal space found that a modular system more efective in lowering the temperature compared the cable system.

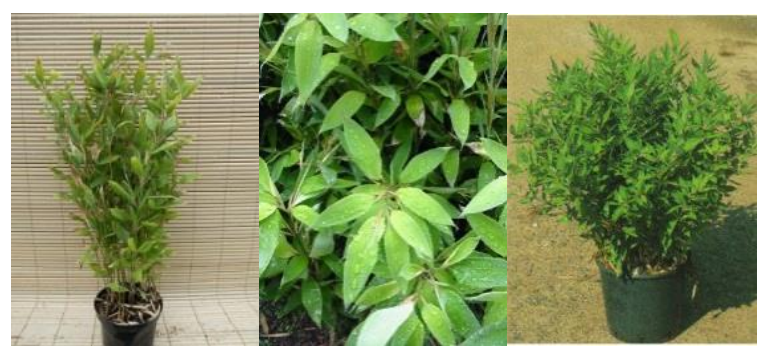

Fig. 1. Shibataea Kumasasa (https://picclick.fr)

The selected vegetation was bamboo species named Shibataea kumasasa. Other names of this type of bamboo, is: Sasaruscifolia, Ruscusblatterbambus (Mausedornblattbambus), originating from: North Japan, China (Anhuei, Zheijiang). These plants are short and broad dark green, grow in small clusters, but are very dense, so the stems remain completely hidden.The height of vegetation in this research is needed 100 centimeter, with the consideration that it can cover sun exposure on walls that cannot be covered by overhang.

\section{The Measurement}

This research took place in design studio at Architecture department, Petra Christian University, Surabaya. This studio placed on 7th floor at about 28 meter from ground level, with windows facing West and North of this design studio. This research done using 2 sets of designing studio window space. One set of window face to West and the other to North. As initial data, retrieval for validity ofindoor air temperatures, indoor relative humidity $(\mathrm{RH})$, indoor light iluminance, taken in March 2019 for 2 weeks.

The choice of a west window orientation regarding its exposed to solar radiation everyday after 12:00 until sunset throughout the year, if it was without shading. North facing windows are chosen because for Surabaya position, the sun in the afternoon hits the North facing windows for 7 months, from March to September every year (Building orientation, https://www.newlearn.info/packages/clear/ thermal/buildings/configuration/building_orientation. html)

Measurements of indoor air temperature and light carried out on conditions with and without vegetation outside the window.The result of the measurement is the effectiveness of vegetation outside the window through comparison of conditions with and without vegetation. So it is more suitable to be applied to passive refrigerated rooms and not appropriate for fully air-conditioned rooms.

Measurement taken using Hobo data logger with measurement items as follow; indoor air temperaturein ${ }^{\circ} \mathrm{C}$, indoor relative humidity $(\mathrm{RH})$ in $\%$ and indoor light illuminance in lux. Measurements representing the dry season, in May 2019. The measurement method, Hobo equipment is placed indoors 1.00 $\mathrm{m}$ from the window with a height of $0.75 \mathrm{~m}$ from the floor, placed on the surface of the desk. Selected placement is in accordance with the activities near the window carried out in the design studio.

To get the studio user's perception of the comfort of the activities in the designing studio, a questionnaire was conducted with a total of 89 students as respondents. The studio user perception asked was the temperature of the indoor air, natural lighting in the studio, the penetration of solar radiation and the presence of vegetation outside the window to the comfort of activities in the design studio. The students of the design studio consisted of 2 groups of studio users, namely students from Designing Studio 4 who used the studio from 7:30 to 12:30 and students from Designing Studio 2 who used the studio from 13.30 to 17:30. 


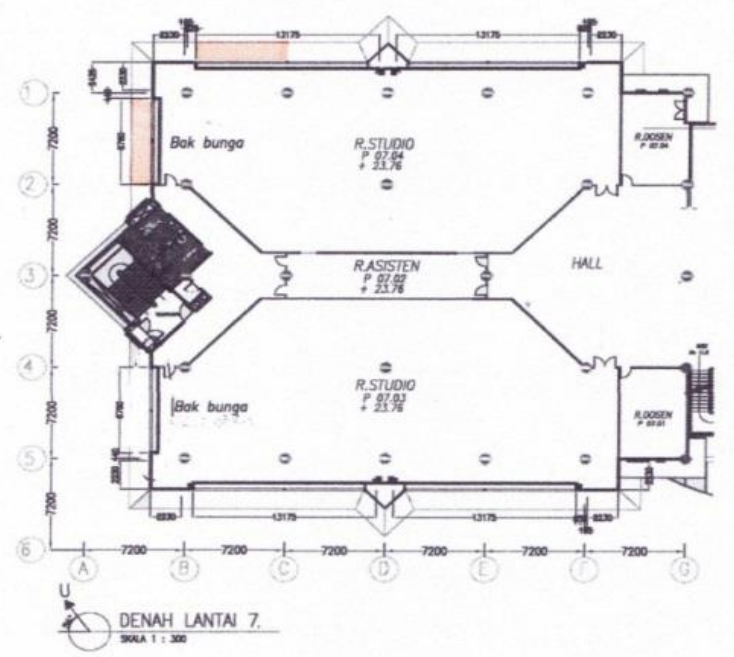

Fig.2. 7th floor plan of Desining Studio

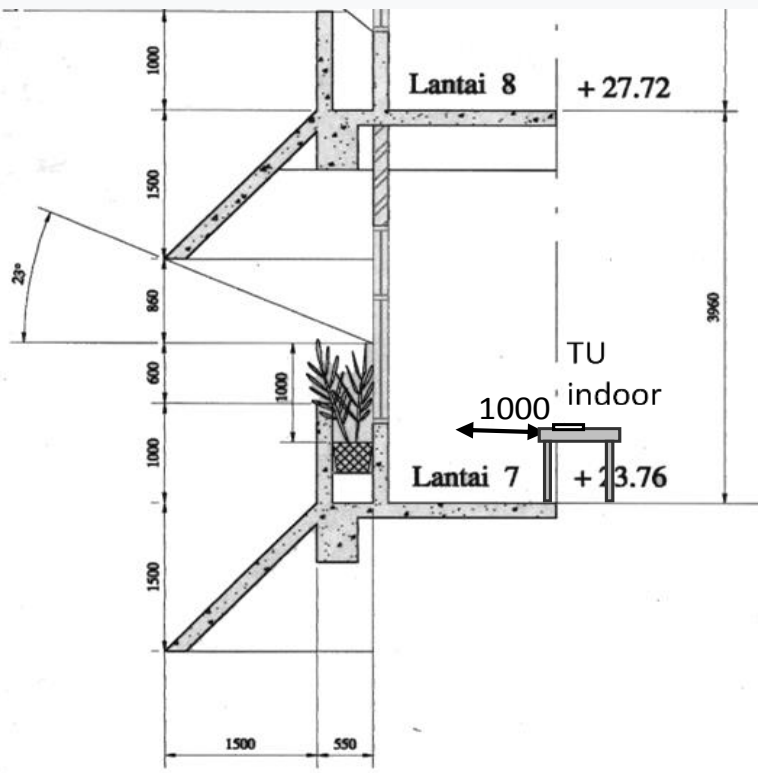

Fig.3. Sketch of vegetation placement and Hobo measurement tools

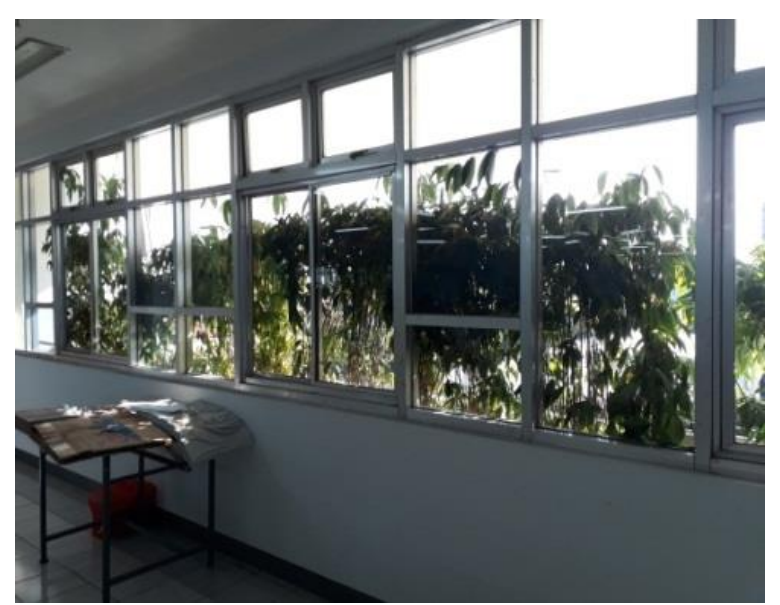

Fig.4. Window opening, West orientation on 15 May 2019, 15.00

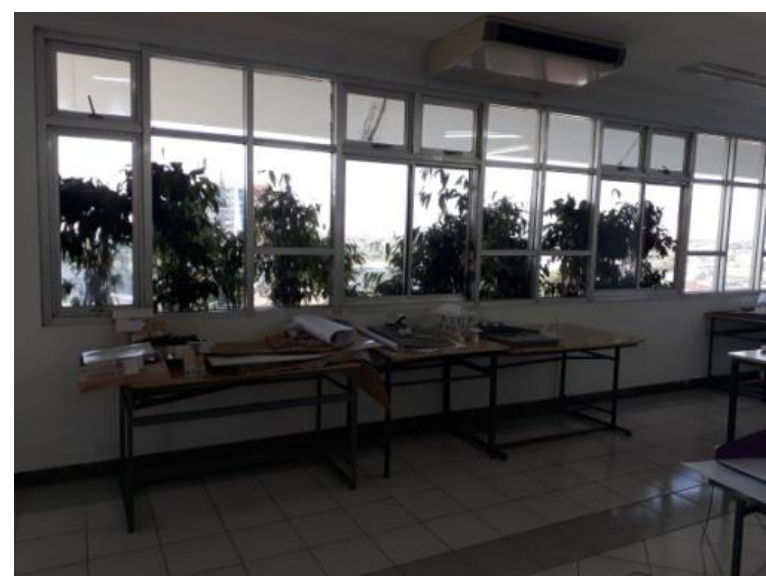

Fig. 5. Window opening, South orientation on 15 May $2019,15.00$

\section{RESULT AND ANALYSIS}

The indoor temperature and the average of indoor relative humidity

North-facing windows, which has no vegetation, indoor temperature at 06:00 pm to $08.00 \mathrm{am}$, around $29^{\circ} \mathrm{C}$, at 09.00 am starting to rise, at $10.30 \mathrm{am}$ reaching $30.5^{\circ} \mathrm{C}$ and decreasing again at $04.00 \mathrm{pm}$. Windowswith vegetation behave the same as those without vegetation, the air temperatures at 06:00 pm to $08: 00$ am in between 28.5 and $29^{\circ} \mathrm{C}$, it increasing starting from $09.00 \mathrm{am}$. At $10.30 \mathrm{am}$ it reaches $30^{\circ} \mathrm{C}$. So the difference between the two conditions is around $0.5^{\circ} \mathrm{C}$.

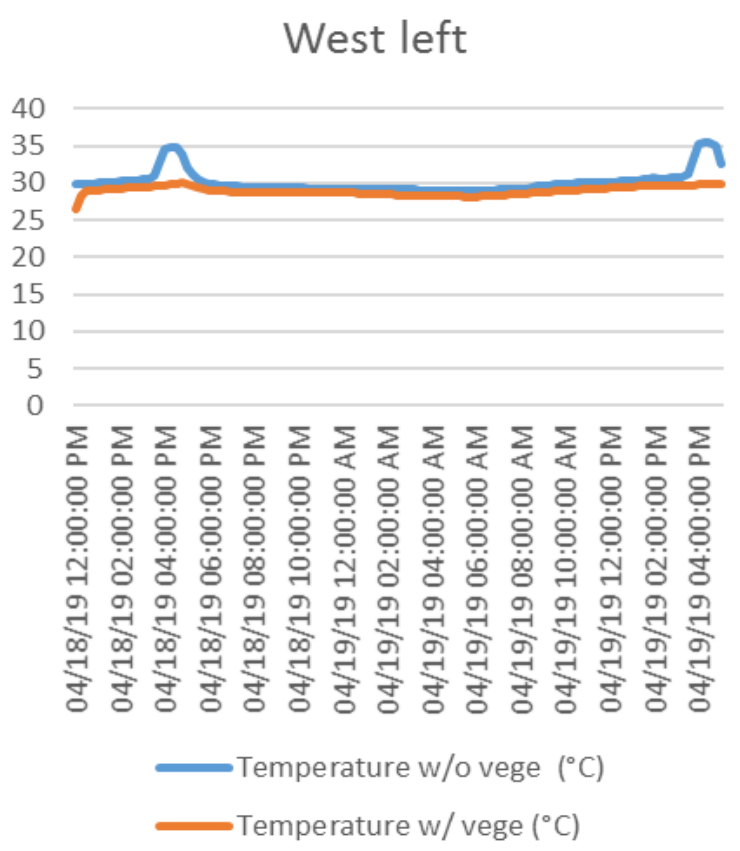

Fig. 6. Non-vegetated and vegetated indoor temperature in West facing window, at the left measuring point 
West right

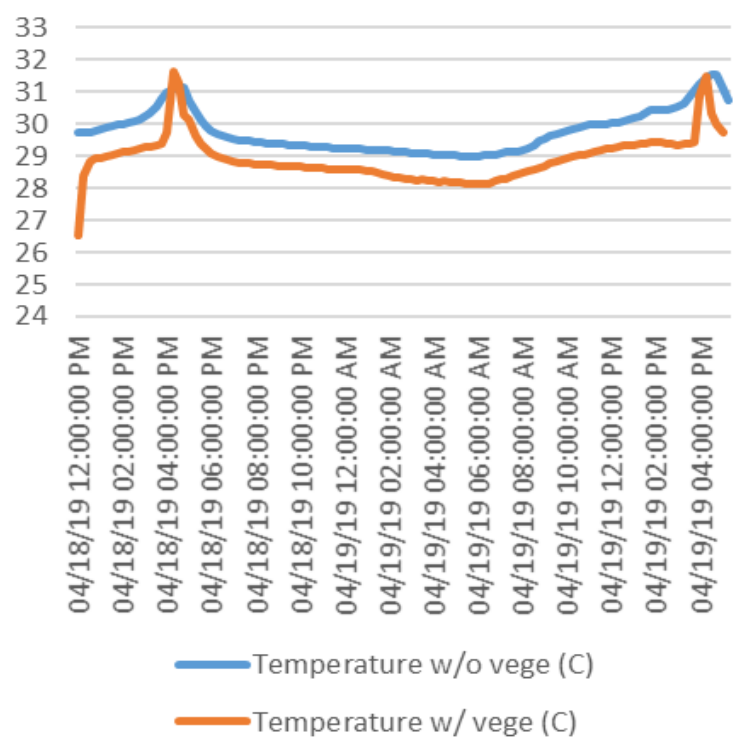

Fig. 7. Non-vegetated and vegetated indoor temperature in West facing indow, at the right measuring point

The relative humidity level at $05.00 \mathrm{pm}$ starts to increase until $10.30 \mathrm{am}$, around $80 \%$ for without vegetation windows, while for with vegetation windows around $70 \%$. Windows with vegetation outside is $10 \%$ dryer than without vegetation. Indoor temperature on windows with vegetation is lower than windows without vagetation but when compared with the thermal comfort temperature, because the comfortable airtemperature of hot humid climatesin the Bioclimatic Chart is in the range of $22-30^{\circ} \mathrm{C}$ with relative air humidity between 18 - $78 \%$.

\section{West left}

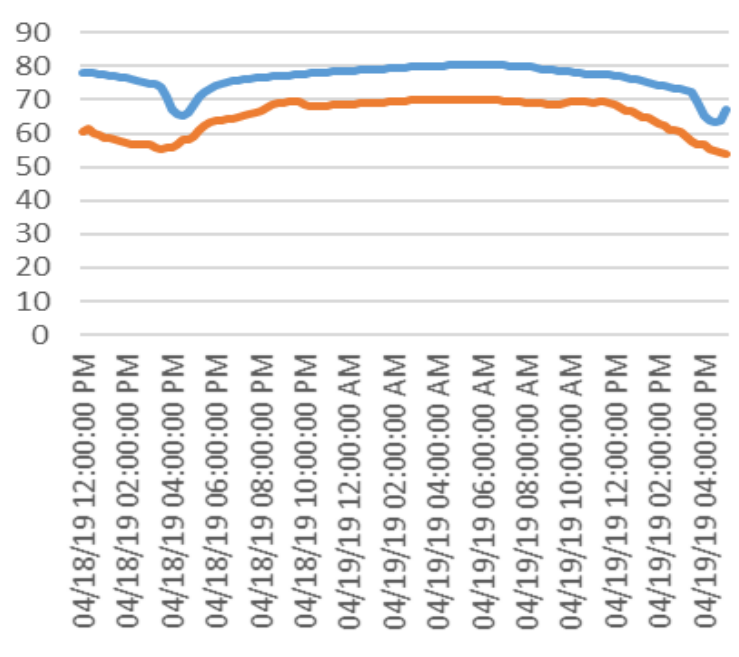

$\longrightarrow \mathrm{RH}$ w/o vege (\%) $\longrightarrow \mathrm{RH}$ w/vege (\%)

Fig. 8. Non-vegetated and vegetated indoor relatif humidity in West facing window, at the left measuring point

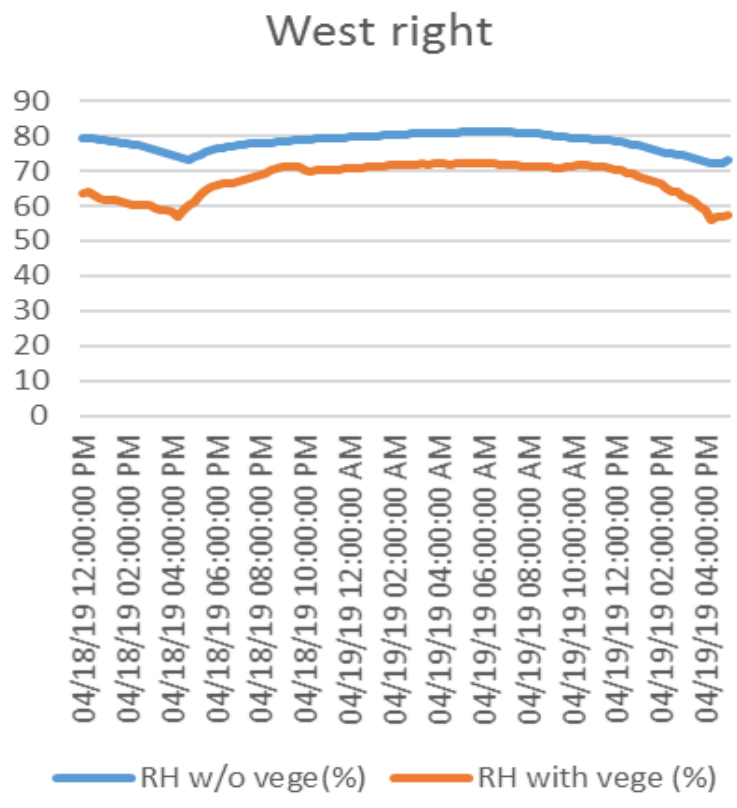

Fig. 9. Non-vegetated and vegetated indoor relatif humidity in West facing window, at the right measuring point

Meanwhile, according to Canada's National Occupational Health \& Safety Resource (CCOHS) research, comfortable conditions in humid tropical climates, temperature between $23-26^{\circ} \mathrm{C}$ with an average humidity of $50 \%$. There is still warmer in air temperature although there are vegetation outside the windows, so to achieve thermal comfort in warm humid climate, cooling still needed. Meanwhile, the relative humidity when compared with thermal comfort, the expected relative humidity is $50 \%$, meaning that air movement is needed.

\section{Illuminance}

Below are graphs the results of measurements of illuminance in lux. Measurements were made on April to May 2019. Lighting conditions were without and with vegetation outside the window. Measuring point in $+0.75 \mathrm{~m}$ in height as the work plane, a distance of $1 \mathrm{~m}$ from the perimeter wall of the room, i.e. at the position of the table closest to the window used by the user of the design studio. The graphs resulted of two indoor measuring points, on illuminance in lux, which were taken at West and North orientation windows.

For West orientations without vegetation, indoor illuminance at $06.00 \mathrm{am}-08.00 \mathrm{am}$ in the range between $30-180$ lux, $08.15 \mathrm{am}-01.00 \mathrm{pm}$ in the range $180-490$ lux, $01.15 \mathrm{pm}-06.00 \mathrm{pm}$ range between $800-5600$ lux at 02:45 pm, then decreases to 0 lux at 06:00 pm.

For West orientation with vegetation, indoor illuminance between $06.00 \mathrm{am}-08.00 \mathrm{am}$ in the range 
of 20 - 110 lux, $08.15 \mathrm{am}-1 \mathrm{pm}$ in the range 110 200 lux (highest), 13.15-18.00 in range $200-350$ lux at 14.45 (the highest) then decreases to 0 lux at 06.00 pm.

By this result, found that for west window, the vegetation can reduce light $37 \%$ (in the morning)95\% (in the afternoon).

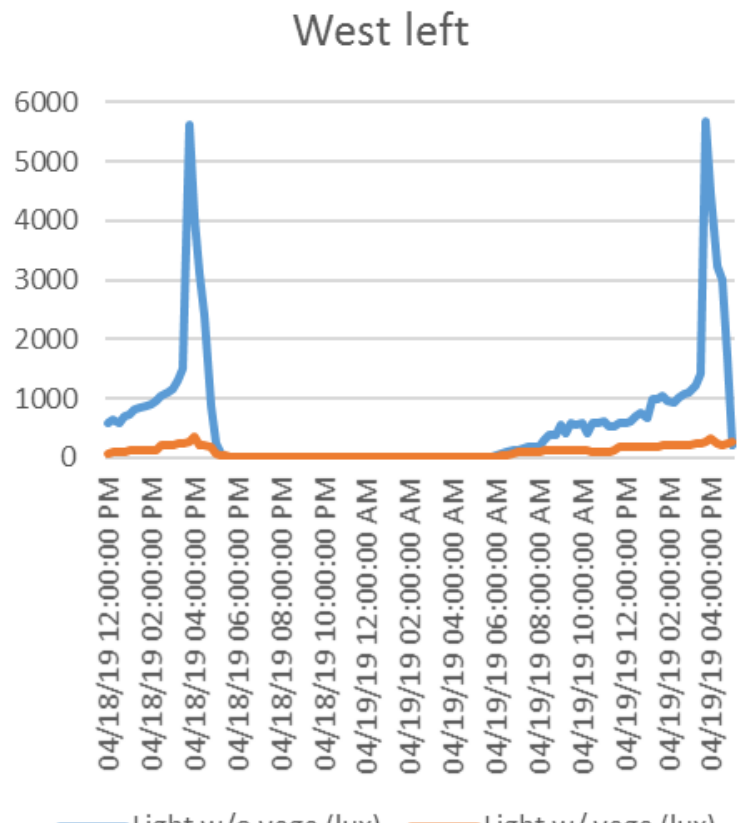

Fig. 10. Indoor illuminance on West facing wall, at the left measuring point

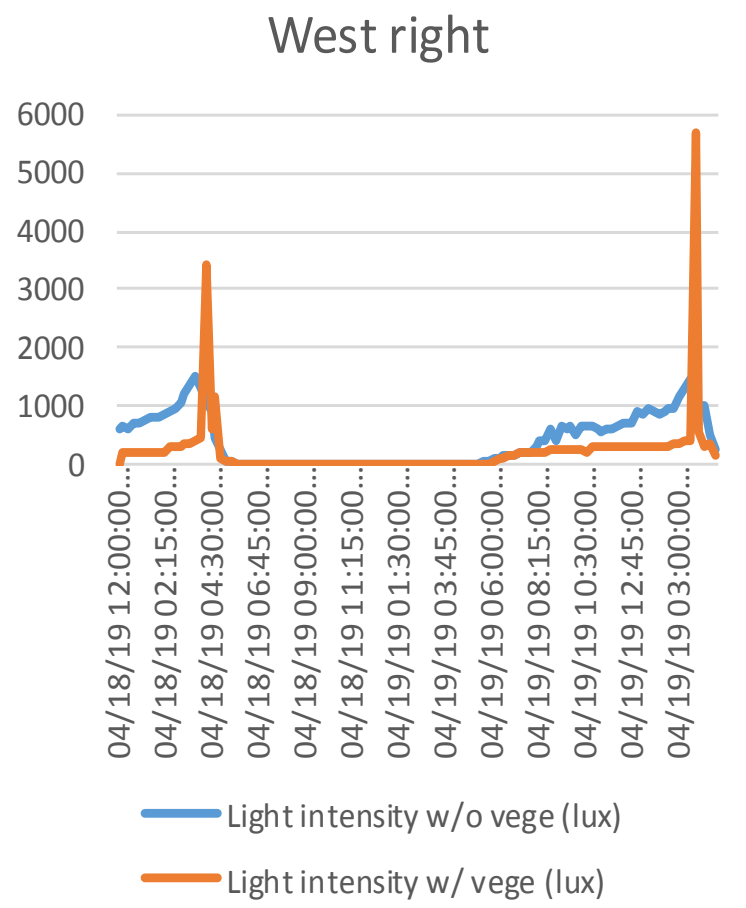

Fig. 11. Indoor illuminance on West facing wall, at the right measuring point

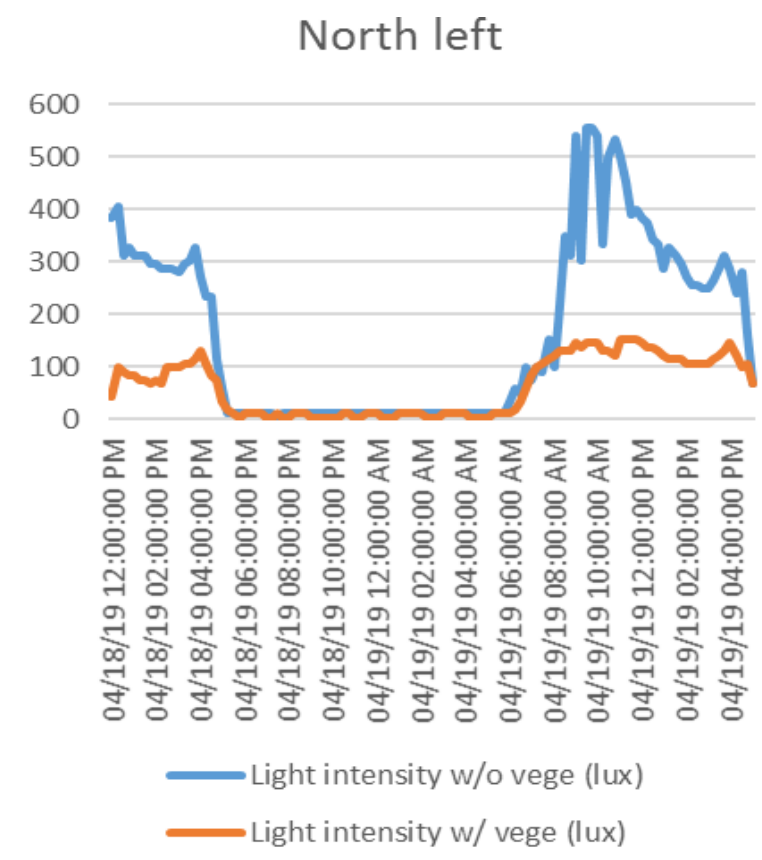

Fig. 12. Indoor illuminance on North facing wall, at the left measuring point

\section{North right}

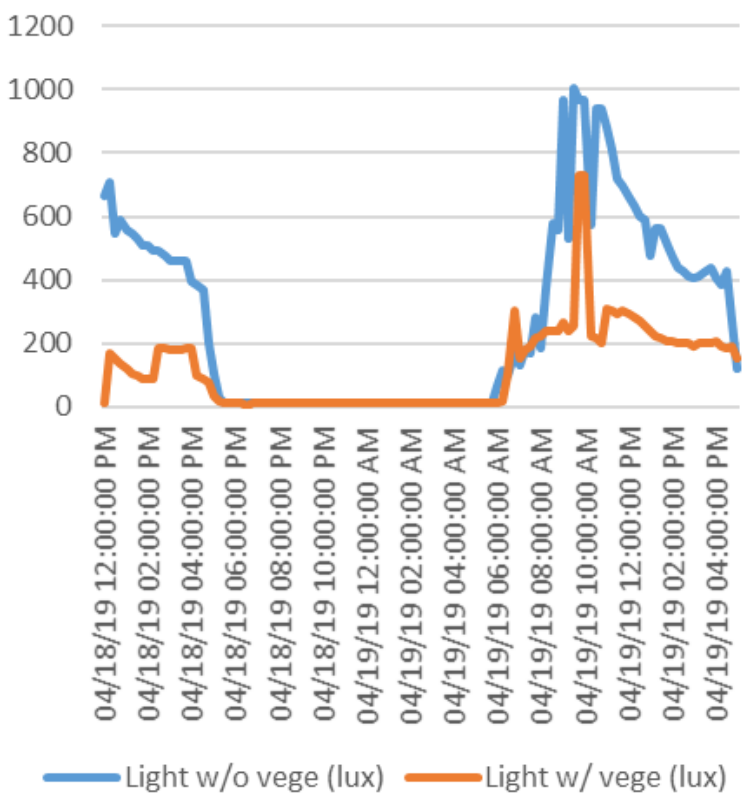

Fig. 13. Indoor illuminance on North facing wall, at the right measuring point

For North orientation without vegetation, indoor illuminance between $06.00-08.00$ in the range of 35155 lux, 08.45-10.45 in the range 210 - 530 lux, at $11.15-16.15$ in the range $500-240$ lux, then decreases to 0 lux at 18.00 .

For North orientation with vegetation, indoor illuminance between $06.00 \mathrm{am}-07.15$ in the range of 20-100 lux, $07.30-16.45$ in the range $105-155$ lux (highest), then decreases to 0 lux at 18.00. 
By this result, found that for North window, the vegetation can reduce light $26-77 \%$ (the highest was at. 10.45).

\section{The student perceptions as users of the design studio room questionnaire resulted}

The respondents were 100 students, while 89 students gave responses, consisting of $49.4 \%$ men and $50.6 \%$ women. The respondents were $33.7 \%$ of the 2nd semester designstudio representing as users from $07.30 \mathrm{am}$ to $12: 30 \mathrm{pm}$ and $63 \%$ of the 4 th semester design studio, representing as users from $13.30 \mathrm{pm}$ to 17:30 pm. Their ages ranged from 17-21 years. The majority of them are 19-20 years old. $47.7 \%$ were 19 years old and $29.5 \%$ were 20 years old. $8 \%$ of 89 students were 21 years old. The rest of them are younger, between $17-18$ years.

$83.8 \%$ of the respondents stated, the solar radiation did not interfere, this was in the condition after there was vegetation outside the window, the rest of them were $16.2 \%$ stated disturbed.

Radiasi matahari pada rg Studio

89 responses

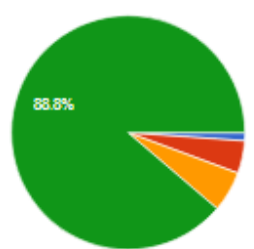

- Terlalu menggangg

- Menggangg.

Cukup Menggangg

- Tilak Menggangg

Fig. 14. Respondent respons to solar radiation after there is vegetation outside the window

According to the daylightingin the design studio, the chart bellow exposed that $60.7 \%$ of the respondents said were just right, and $30.3 \%$ said it was bright enough, so that it could be said that $91 \%$ of the respondent, said that the natural lighting in the design studio for drawing activities was adequate, even though there was vegetation outside the window. While $9 \%$ of them think that the lighting in the studio was inadequate. In this case, no student felt that the daylighting was too bright.

\section{Pencahayaan alami pada rg Studio} 89 responses
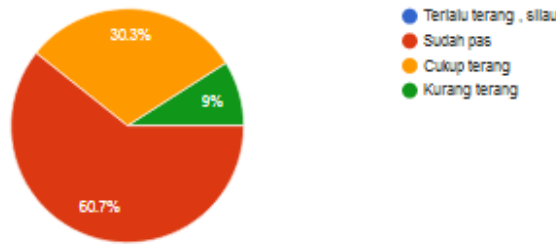

Fig. 15. Respondents' statements about day lighting in the design studio
View through the window that allows students to rest their eyes for a moment and see the natural surroundingswas also a source of daylighting for this studio. The responds, for view or view out through the window is $51.7 \%$ of the respondents felt very necessary, $32.5 \%$ felt needed, while $15.7 \%$ had no problems, so it can be concluded that the view through the window was needed for the design studio. No one feels view outside the window was unnecessary.

\section{View dari jendela ke luar Studio} 89 response
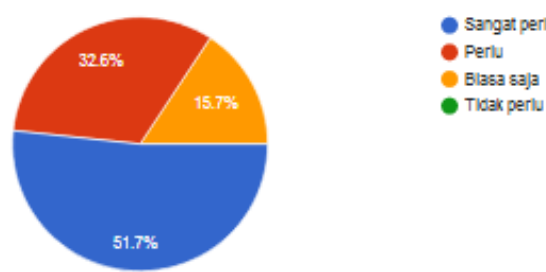

Blasa saja

- Tidak perlus

Fig. 16. The need of view outside the window stated by the respondent

Regarding vegetation for the design studio, the result were $21.6 \%$ stated that it was very necessary and $36.4 \%$ said it was necessary, so that it can be said that $58 \%$ respondents had expectation for natural element such as plants for their design studio.

Elemen natural misalnya tanaman utk rg Studio

88 responses

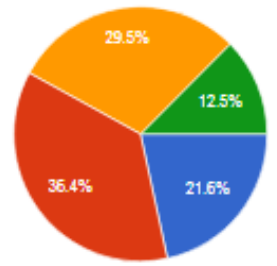

Sangat peri: Perlu.

Blasa saja

- Tidak perl.

Fig. 17. Respondent's statement of plant needs for the design studio view

As a design studio whose activities are primarily drawing building designs, $41.6 \%$ of respondents stated that vegetation affectvisual comfort, and $36 \%$ felt little impact, while $14.6 \%$ said it was indifference. Only $7.9 \%$ said it was useful as view.
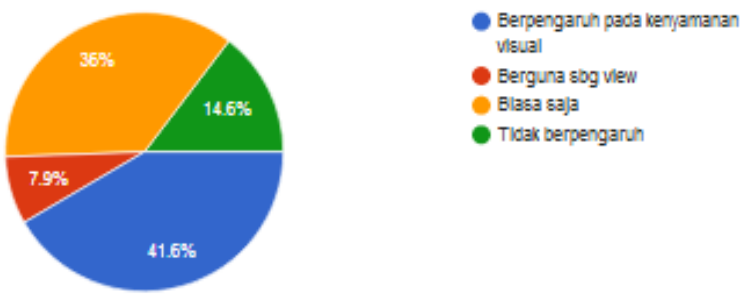

Fig. 18. The importance of visual comfort in designing studios 
One thing that's quite a problem in design the studio's, stated by respondents was the arrangement of the table against the activity space, which was stated by $34.5 \%$ of respondents, whereas $49.4 \%$ of respondents stated that the space for activity was appropriate.For additional from these 89 respondents, comfortable studio depends on: $8.3 \%$ the importance of protection the solar radiation penetration, $20.2 \%$ the daylighting, $17.9 \%$ the electric lighting, $34.5 \%$ the dimensions and layout of the room; $10.7 \%$ view through the window and $8.3 \%$ choose natural elements (plants).

\section{CONCLUSION}

From the measurement results obtained, window facing West and North in the presence of vegetation outdoor the window, the lowest indoor air temperature was $27^{\circ} \mathrm{C}$ with an average relative humidity of $70 \%$. It positioned at the upper edge to the thermal comfort of Olgyay's Bioclimatic Chart and Canada's National Occupational Health \& Safety Resource (CCOHS), so that cooling was needed to get indoor thermal comfort.

According to SNI 03-6197-2011, illuminance for design studios is 750 lux. From measurements obtained for West-oriented windows with outside vegetation, the highest was 350 lux at $02: 45 \mathrm{pm}$, as well as for windows facing North at $07.30 \mathrm{am}-04.45$ $\mathrm{pm}$ in the range between 105-155 lux (highest). For North orientation, the illuminance was lower than the west. So that, with the vegetation outside the window, it will require electric lighting addition.

Whilst the design studio user as the respondent stated that vegetation was expected for natural element, blocked the penetration of solar radiation into indoor, and reduce glare to increase visual comfort without reducing luminous sufficiency for the activities in the design studio.

\section{REFERENCES}

Building orientation. Accessed from Comfortable Low Energy Architecture online on September, 11th 2019.

https://www.newlearn.info/packages/clear/thermal/bu ildings/configuration/building_orientation.html

Coma, J. et al. (2017). Vertical greenery system for energy saving in building: A comparative study between green walls and green facades, Building and Environment, 111, 228-237.

Geiger, R. (1957). The Climate Near the Ground, 2nd edition. Harvard University Press: Cambridge, M.A.

Health and Safety Programs. (2019). Thermal Comfort for Office work, OSH Answers Fact Sheets. Canadian Centre for Occupational Health \& Safety, Government of Canada.

Ibrahim, N. L., \& Hayman, S. (2005). Daylight Design Rules of Thumb. Proceeding Conference on Sustainable Building South East Asia, 11-13 April 2005, Malaysia.

Jaafar, B., Said, I., Reba, M.N.M., \& Rasidi, M.H. (2013). Impact of vertical greenery system on internal building corridors in the tropic. Social and Behavioral Sciences, 105, 558-568.

Kelembaban, Tekanan Udara dan Temperatur Udara Rata-rata Per Bulan Tahun 2012-2014. https://surabayakota.bps.go.id/linkTabelStatis/vi ew/id/194

Miller, D.H. (1955). Snow cover and climate in Siera Nevada, Barkeley, California. Univ California Press. California

Montachinni, E., Tedesco, S., \& Rondinone, T. (2017). Greenery for an University Campus: does it affect indoor environmental quality and user well-being? Energy Procedia, 122, 289-294

Olgyay, V. (1963). Design with Climate, Bioclimatic Approach to Architectural Regionalism. Princeton University Press.

Othman, A.R., \& Sahidin, N. (2016). Vertical Gardening Facade as Passive Approach in Sustainable Design, Social and Behviorial Sciences, 222, 845-854.

Post graduate. (2012). Manfaat vegetasi pada estetika. http://agrotekacehgmail.blogspot.com/2012/05/ manfaat-vegetasi-pada-estetika.html

Robinette, G.O. (1983). Energy Efficient Site Design. Van Nostrand Reinhold Company, New York, USA.

Robinette, G.O. ed. (1983). Landscape Planning for Energy Conservation, Van Nostrand Reinhold Company, New York, USA.

Shibataea kumasasa https://picclick.fr

SNI 6197:2011 Standar Nasional Indonesia. Konservasi Energi Pada Sistem Pencahayaan. Badan Standardisasi Nasional, Indonesia.

Szokolay, S.V. (1980). Environmental Science Handbook, for architects and builders. Lancaster, UK. 